\title{
Of CINEMA
}

CELESTINA. color. Director: Miguel Sabido; With Isela Vega, Ofelia Guilman, Marcela López Rey. Distributed by Columbia Pictures.

A better title for this film would be "Perversiones sexuales." In an attempt to modernize the Celestina, the director has focused on and exaggerated all sexual possibilities suggested by Rojas' characters. In a surrealistic and bloody dream sequence, the nude Calisto is castrated. Celestina has lesbian tendencies especially when she fondles and caresses Melibea while talking to her about Calisto. The servants spend much time at Celestina's house, which is a center for sex orgies. Calisto incessantly complains, sounding more like a paranoid schizophrenic than a man in love. Melibea, who looks closer to 40 than to 20 ; is well beyond her prime. She is a redhead, not a blond, and is not a suitable partner for Calisto both physically and temperamentally. Celestina is good but too young for this crowd:

The whole movie is over-acted and teeming with unnecessary violence. The twisting of the hawk's neck at the beginning and later its being chopped up is effective as a film technique but is a brutalization of Fernando de Rojas' own use of imagery.

There is so much shouting, violence, street language, and perverted sex in this movie that one gives a sigh of relief at Calisto's death. One feels that the finer qualities and artistic merit of the original have all been eliminated. The characters parade across the screen in Medieval garb shouting:modern insults at one another. Technically, the movie is well-done, but the director has simply gone too far in trying to make the Celestina appealing to a twentieth century audience. Even expurgated, this is definitely NOT a film for the classroom!

MARY-ANNE VETTERLING Northeastern University 